Svetlana Biryukova, Oxana Sinyavskaya

\title{
Children OUt Of parental CARE In RUSSia: WHAT WE CAN LEARN FROM THE STATISTICS
}

The paper presents a detailed analysis of the Russian official statistics for orphans and children placed out of parental care. Employing a wide range of data sources, the authors show that in Russia, the primary risk of orphanhood remains high. Although it has declined over the last fifteen years, in 2015, the share of children taken out of parental care exceeded two percent of the total number of children under eighteen. At the same time, statistical data confirms the ongoing deinstitualisation of the Russian care system, a trend that has continued since the mid-2000s. Thus, $11.5 \%$ of children out of parental care were institutionalised in 2014, whereas in 2000 this share amounted to as much as $27 \%$. However, the authors argue that the current childcare system reproduces a number of serious systemic problems. Firstly, despite the fact that over $80 \%$ of children entering the Russian care system per year have living parents, reuniting the children with the birth family is not yet recognised as a primary objective of the policy; according to the official statistics, only one out of ten children goes back home after being taken out of parental care. Secondly, for particular groups of children it is often hard to arrange family placements. Until now, the higher risks of longterm institutionalisation are noticeable in children placed out of parental care at the age of three years or older. This problem is particularly serious for teenagers, as well as for children with physical or mental disabilities. Thirdly, the prevalence and dynamics in children returning to institutions from foster placements highlight the importance of professional training for foster parents and the need for consistent guidance for foster families, aspects that are still underdeveloped in Russia. In the last section of the paper, authors discuss

Svetlana Biryukova - Kandidat nauk (PhD) in Economics, Leading Researcher, Centre for Comprehensive Social Policy Studies at ISP NRU HSE, Moscow, Russia. Email: sbiryukova@hse.ru

Oxana Sinyavskaya - Kandidat nauk (PhD) in Economics, Director of Centre for Comprehensive Social Policy Studies at ISP NRU HSE, Moscow, Russia. Email: osinyavskaya@hse.ru 
one possible outcome of this analysis with reference to policies aimed at children left out of parental care.

Key words: children out of parental care, social orphanage, foster families, institutional placements for orphan children, deinstitutionalisation of orphan care, statistics, Russia

DOI: $10.17323 / 727-0634-2017-15-3-367-382$

\section{Introduction}

Over the past fifteen years, Russian society has faced major changes both in terms of overall economic conditions and in the child welfare system, which have led to fundamental changes in the field of child abandonment and support for children out of parental care. On the one hand, sustainable economic growth from the early 2000 s until recently resulted in poverty reduction and enhanced the population's economic condition. These changes by themselves might have led to an improvement in the child abandonment dynamics. On the other hand, since the mid-2000s, the child welfare system has undergone continual deinstitutionalisation. Strictly speaking, the priority of family placements and the temporality of institutional care were inscribed into the Family Code (Family Code 1995: article 123.1). On a theoretical level, deinstitutionalisation of child care, which was substantially advocated by the NGOs and expert community, is associated with attachment theory, which views a stable and meaningful relationship between a child and at least one primary caregiver as a necessary condition for his or her successful social and emotional development (Ainsworth, Bowlby 1991). These principles were confirmed in respect of orphans in numerous observational studies (see Dozier et al. 2012 for a review), including some that were carried out in Russia (Groark et al. 2005). However, the trend towards deinstitutionalisation in Russia became more pronounced at the legislative level and in practice after the 2006 Presidential Address to the Federal Assembly, after which regions were directly instructed to develop mechanisms to reduce the number of institutional placements.

Overall, Russia remains a country with one of the highest proportions of children out of parental care and a still relatively high level of institutionalisation among such children. Although both Russian officials and society acknowledge the importance of this problem, we still know very little about the dynamics of the number of children out of parental care, their characteristics or how foster care is developing in Russia. Data on the number of children out of parental care is often incomplete and sometimes contradictory (Ovcharova, Yarskaya-Smirnova 2010). Here we discuss some of the limitations in the first paragraph of this paper.

This paper presents a diagnostic overview of the statistics on child abandonment and care for 2000-2015. Partially, we reproduce the review presented in Svetlana Biryukova et al. (2013) over a shorter period of time, from which we would expect to see a continuing fall in the prevalence of orphanhood 
driven by the reduction in child abandonment (social orphanhood) together with the ongoing deinstitutionalisation of the Russian child care system. These two elements are the subjects of the second and third sections of the paper. In the fourth section, we expand the scope of the paper and investigate some of the issues relevant to the ongoing process of deinstitutionalisation. This paper suggests that this process might have affected different groups of children unevenly. Namely, we expect its results to be less promising for children with disabilities, as was also the case in some other European countries (UNICEF 2012), and for older children.

In addition, it can be suggested that these statistics should reflect the consequences of the policies introduced after the adoption of the Dima Yakovlev Law. The generous lump sum benefits announced to support families adopting children with disabilities, siblings and children of older age groups provoked a rise in the number of their family placements. This might have also caused an increase in the number of returns in the following years. Indeed, the tone of the media and public debate together with the attractive measures of financial support could have pushed undertrained or unprepared parents to adoption, and we should expect to observe related changes in the dynamics of indicators referring both to adoptions and following returns or (repeated) abandonments. All of these assumptions will be considered on the basis of available statistics.

In the paper, we use the following terminology: guardianship (guardians) refers to gratuitous family-based care (opeka for children under 14 years old and popechitelstvo for older children in Russian), while foster families (parents) means paid family-based care (priyomnie semyi). To embrace all these care types, together with adoption, we use term replacement parenting.

\section{Data}

The Russian systems for detecting at-risk children and for childcare include many actors operating at the federal, regional and local levels. Due to this reason, statistical information regarding children out of parental care is collected by different agencies. For example, the Russian Federal State Statistics Service (Rosstat) gathers data from the Ministry of Healthcare, the Ministry of Labour and Social Protection and the Ministry of Education and Science. The available statistical data on the children out of parental care is not without shortcomings. Firstly, the plurality of the data sources sometimes produces inconsistencies. Thus, in certain years, the Rosstat aggregated estimates of the total number of children out of parental care differ from those extracted from federal statistical forms published by the Ministries due to differences in the applied aggregation method (for more detail, see Ovcharova, Yarskaya-Smirnova 2010). Secondly, some important processes are not reflected in the statistics due to the complexity of their measurement. In particular, a major problem is the inability to estimate the number of institutionalised children without orphan status who cannot be 
considered for family placements while having blood parents with their parental rights in force. Among them might be children of those temporarily imprisoned or children with severe disabilities placed temporarily, but not necessarily for a short period of time, in institutions at the request of their parents. According to the formal definition, these children are not out of parental care and are not included in the relevant statistics. However, they may in fact stay in institutions without any contact with their relatives for a long time, forming an invisible or latent sector of so-called social orphans.

Despite the indicated shortcomings, an analysis of the existing statistics allows us to track the general dynamics in the sphere of orphan care, and within this paper, we present a comprehensive review of the available data. Firstly, we consider yearly federal statistics of the 103-RIK forms on the detection and placements of children and adolescents out of parental care. ${ }^{1}$ Secondly, we review D-13 yearly federal statistics on institutions for orphans and children out of parental care. ${ }^{2}$ Finally, we also include aggregated Rosstat data.

\section{Child Withdrawal and Reduction of Orphanhood}

According to the Rosstat data, the total number of children out of parental care, which includes children placed in institutions of any type, as well as children in family-type placements, has been shrinking since 2005 (see Fig. 1). In the ten years from 2005 to 2014, the number of children without parental care increased only once, in 2007 , by 500 children over the previous year. This tendency set in after a period of steady growth of this indicator, spanning from the early 1990s until the mid-2000s, a period which was marked at the beginning by a highly volatile macroeconomic situation and decline in living standards, and by improvements in the system for identifying troubled families at the end.

In 2004, when this indicator was at its highest, there were 726,900 children without parental care in Russia but by 2015 this figure had fallen to 613,300 . Thus, over the last decade, the number of children without parental care has decreased by $15.6 \%$. The number of children taken out of parental care during a calendar year shows a similar trend: this indicator was at its highest in 2005, when 133,000 children were identified, and it fell to 58,200 in 2015 (Fig. 1). In other words, the number of children taken out of parental care during a calendar year has decreased by more than half (by $56 \%$ ) over the last ten years.

Relative indicators show a somewhat different trend. The decline in the number of children without parental care in 2005-2009 was related first of all to the general dynamics of Russia's children population. The latter was declining

\footnotetext{
${ }^{1}$ Form № 103-RIK contains data on the number and demographic structure of children out of parental care, as well as the information about their placements

${ }^{2}$ Form № D-13 contains data on the material equipment, financial stability, personnel and fullness of the institutions of different types;
} 
steadily, and the number of children without parental care as a proportion of all children in Russia continued to grow at that time, climbing as high as $2.8 \%$ in 2009 (Fig. 1), only beginning to decline slowly in 2010. The dynamics of the share of children without parental care identified during a calendar year is somewhat different, showing a positive trend already in 2006-2007. In these years, this category accounted for $0.5 \%$ of the total number of children under seventeen, and in 2014/2015 it was as low as $0.2 \%$. This kind of dynamics may be evidence of a gradual improvement in prevention work with at-risk families since 2005.

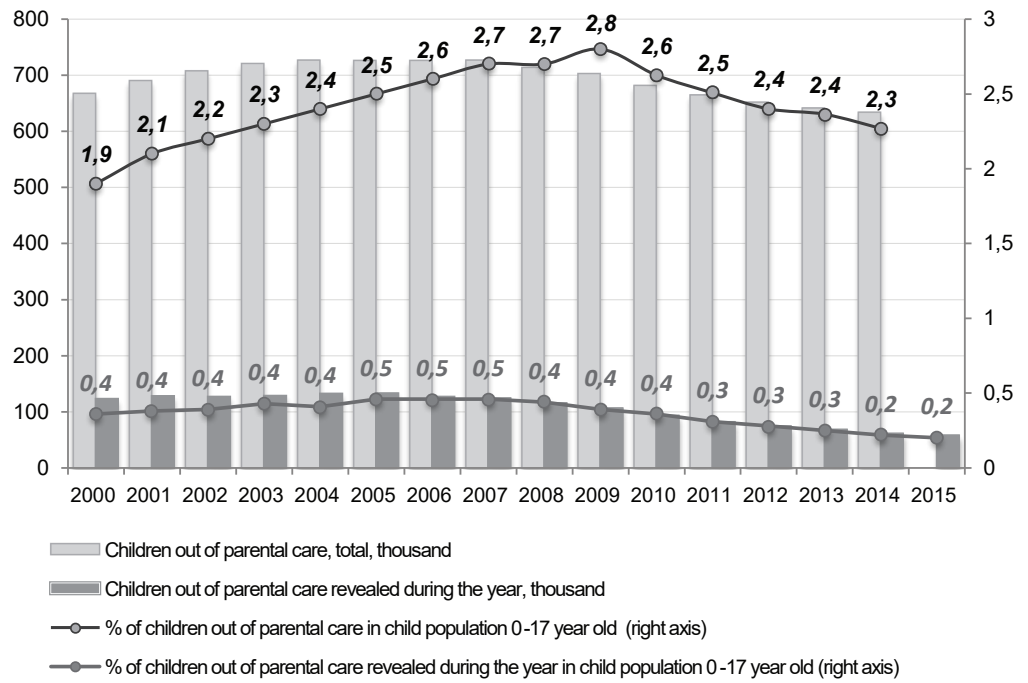

Figure 1. Children without parental care, 2000-2015

Source: Rosstat, statistical form 103-RIK

Most children without parental care in Russia are so-called social orphans, which means that they have at least one living parent while being placed into childcare system. Although the number of biological orphans as a proportion of all children without parental care has been growing since 2009, it remains at around $20 \%$ (Fig. 2). More than one half of identified at-risk children become wards of the child placement services at school age (6 years old) or older. In the last decade, the number of children younger than seven as a percentage of all children identified as at-risk during a calendar year has fluctuated between $40 \%$ and $45 \%$ and does not show a tendency to grow (see Fig. 2). At the same time, both Russian and international experience shows that it is much more difficult to find family placements for older children who have more trouble adapting to replacement families, as well as establishing enduring attachments and contact with adults who replace parents. 


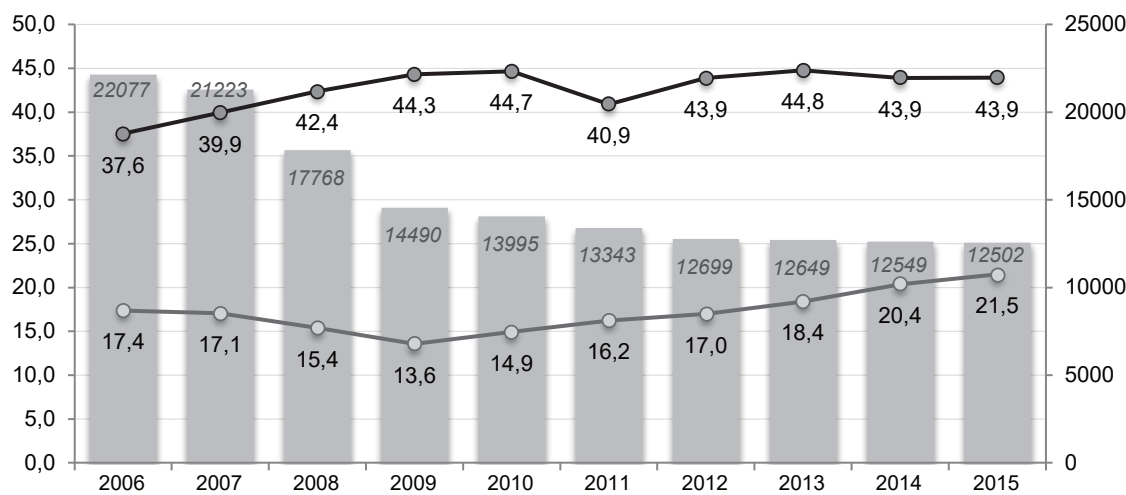

Number of orphans revealed during the year, persons (right axis)

- Share of children 0-6 year old in total number of children without parental care revealed during the year, \%

- - Share of orphans in total number of children without parental care revealed during the year, \%

Figure 2. Orphans and children without parental care under 7 years old, 2006-2015 Source: Statistical form 103-RIK

The dominant method of child withdrawal in Russia is terminating parental rights, which is a very tough measure narrowing the possible scope of further efforts to reunite families. In 2015, the parents of 40,000 children had their parental rights terminated, including 26,000 children whose both parents or single parent were divested of parental rights, whereas the option of limiting parental right was applied to parents of 9,400 children (see Fig. 3). This corresponds to 33,400 parents divested of parental rights and 7,200 parents whose parental rights were limited. The predominant reason for terminating parental rights is neglect of parental responsibilities, including willful evasion of the payment of child support - this reason is cited in $76 \%$ of all cases of full termination. Apparently, the situation of negligent parenting calls for an intervention on the part of the child protection services or other public bodies but perhaps not for such a drastic measure as full termination of parental rights.

At the same time, looking at Fig. 3, one cannot fail to notice positive dynamics in this sphere. In absolute terms, the number of children whose parents had their parental rights terminated has been steadily declining since the end of the last decade: 76,300 in 2008 and by 2015 this figure was already down to 40,000 . This reduction has been conditioned by a gradual decrease in the overall number of identified at-risk children and by a growing incidence of the cases of limitation of parental rights. The total number of such cases has been steadily growing over the entire period under review, from 2000 to present, and their share in the total number of child protection decisions has been rising since 2005, growing threefold, from $5.7 \%$ to $17 \%$ in 2015 . 

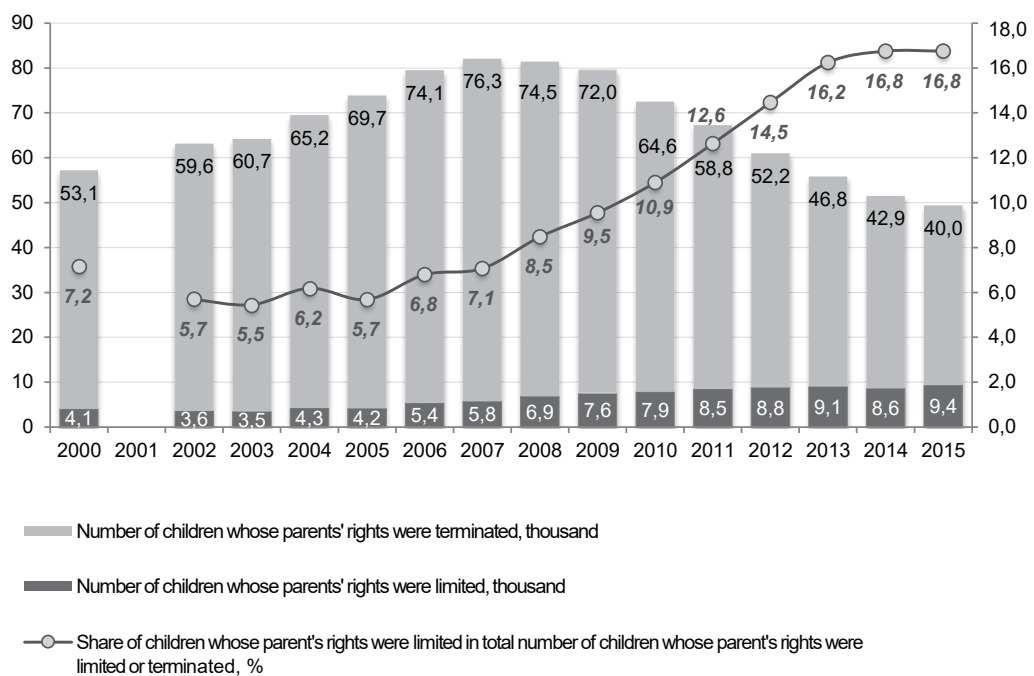

Figure 3. Children whose parents' rights were limited or terminated, 2000-2015 Source: Statistical form 103-RIK. No data for 2001

\section{Child Placements and Accelerating Deinstitutionalisation}

\section{Institutional placements}

The dynamics of the rank order of the placement options used for children without parental care clearly reflects the process of deinstitutionalisation taking place in Russia since the mid-2000s. The legislation prioritises family placements over institutional options, and the statistics reflects this priority: in 2000-2015 the share of children placed at baby and children's homes and other residential care facilities declined by almost two thirds, from $27 \%$ to $10 \%$ (Fig. 4). Moreover, by now institutional placements have become the least popular, although before 2007 institutions were almost the most often used option, second only to guardianship.

The most important characteristic of institutional placements for children without parental care is the size of institutions and the number of children in a group handled by a single caregiver. It is generally believed that small groups and small-sized children's homes are better for forming a stable relationship with a caregiver (see Williamson, Greenberg 2010), and this thinking is reflected in the key points of Decree 481, issued in 2014, which emphasizes family-type care in children's homes. Yet, according to Rosstat, the number of children staying at family-type children's homes during the period under review remained miniscule: by 2005 such institutions accommodated 350 children and by 2014 the number was down to 67; in 2015 it grew to 272 . The main reasons for this is that in Russia, family-type children's homes were only legally established in 
2001, and are, in fact, two-parent families fostering five to ten children at one time, which is still a rare case (Decree 2001).

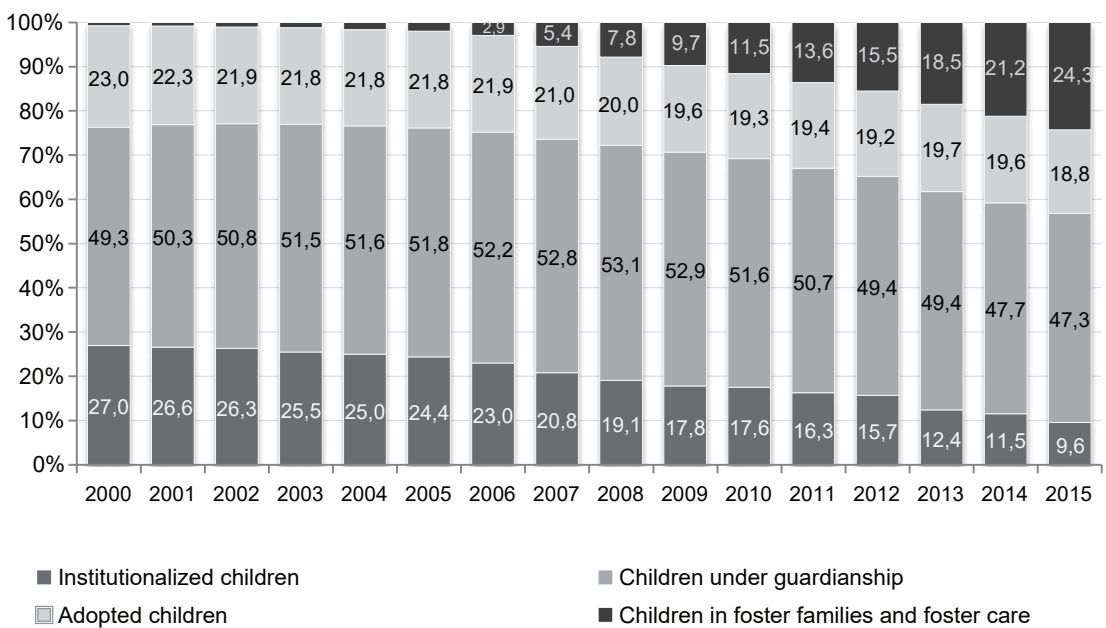

Figure 4. Structure of children placements, 2000-2015

Source: Rosstat

For the last five years, there is no available data on the structure of the institutions for children without parental care by their size. However, in 2011 small-sized children's homes (accommodating maximum twenty children) accounted for $6.3 \%$ of the institutions, and large facilities (more than 100 children) for $17.1 \%$ (Semja 2012). The remaining $76.6 \%$ were medium-sized children's homes. At the same time, data provided in the 103-RIK forms shows that in 2015, ten children in a group was the required norm for most institutions whereas in fact groups included about eight children each. This statistic is differentiated by institution type: on average, groups in specialized (correctional) children's homes, and especially in specialized residential schools, are larger (see Fig. 5). This runs contrary to the organizational logic of the treatment of different types of children since it is precisely the wards of special (correctional) institutions that require more attention and care, and a small size of the group and individual approach are especially important for this category of children.

Children older than six years predominate in the population of children who stay at institutions long term. In the population of children raised at state-run institutions, in 2015 the combined share of children older than six years of age was $90.9 \%$, with children aged seven to fifteen accounting for $69.3 \%$ and children older than sixteen for $21.6 \%$. One of the main reasons why older children get placed with families less often is the statutory need to secure consent for children 
aged ten years old or older. And as for the younger children placed at institutions, their share is higher among residents of correctional children's homes (Fig. 6) this shows that most children younger than seven years who do not get family placements are those who have problems with health or vital functions.

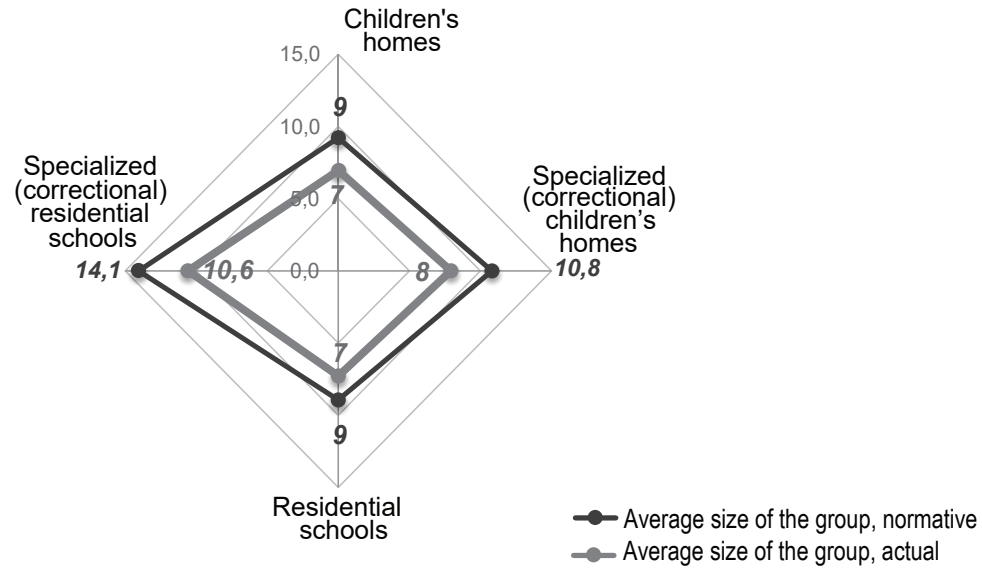

Figure 5. Average size of the groups in children's homes and residential schools for children without parental care, 2015

Source: Estimates on the statistical form 103-RIK data

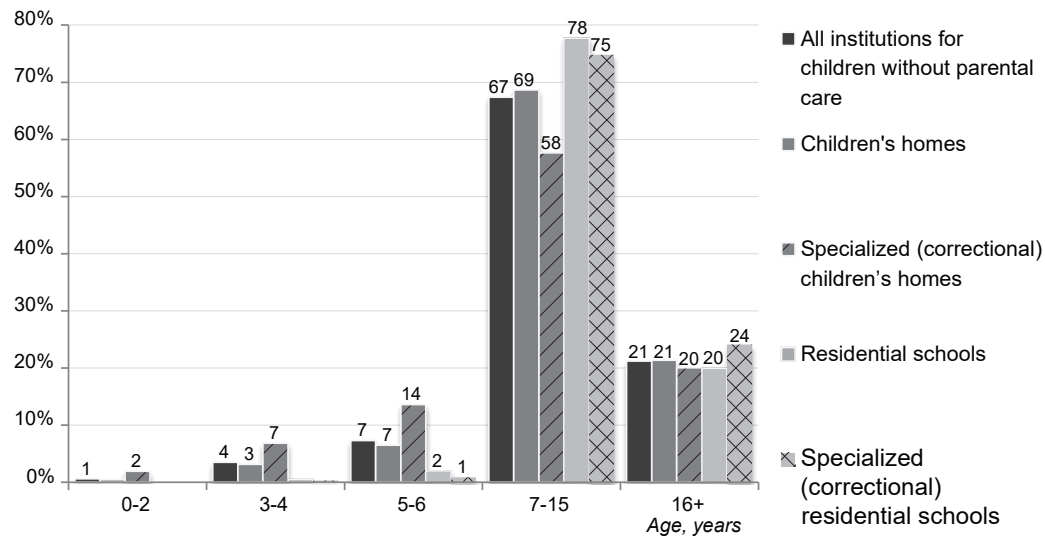

Figure 6. Children living at different types of institutions: breakdown by age group, 2015 Source: Estimates on the statistical form D-13 data 


\section{Family placements}

The dominant family placement option during the entire period under review was guardianship. In 2001-2011 these placements accounted for more than half of all family placements. In recent years this share shrank, albeit insignificantly: in 2015, $47 \%$ of all children without parental care were placed with guardians (Fig. 4).

Currently, the most dynamically developing form of family placement for children without parental care are foster families. In 2005-2015, the share of children placed with foster families grew from $2 \%$ to $24 \%$, which is more than tenfold (Fig. 4). This rise was promoted, inter alia, by Federal Law No. 48-FZ On Guardianship and Fostering, adopted in 2008. There are several separate trends underpinning the spread of fostering. First, it is crucial transformations of social values and public mood that followed the change in the state's attitude to orphans in the early 2000 s, emphasizing their vulnerability, rather than deviance. Second, it is the gradual development of the institution of foster families, including the creation of schools for them and the system of their selection and assistance to them. And thirdly, the increase in the number of children raised by foster families is partially explained by the fact that some guardians made new official arrangements, in order to gain access to services and benefits provided by Law No. 48-FZ, such as professional support and financial assistance, including foster parents' salaries and money allowances for food, clothes and other child-related expenditures.

Given these tendencies, since 2006 the share of adoptions in the placement options for children without parental care has been slightly declining. In 2000-2006 about $22 \%$ were being adopted, and then this figure went down to 19-20\%, remaining at this level ever since (Fig. 4).

\section{Unaddressed Problems}

Along with these, mostly positive, changes, the Russian system of care for children without parental care has been persistently experiencing several serious problems. Following the assumptions formulated in the introductory part of the paper, in this section we will focus on three of them.

\section{Repeated orphanhood}

Although the total number of cases when children were returned from family-type placements to institutions has been declining since 2010, the statistics for 2015 recorded a rise, with 5,329 children returned in 2014, and 5,648 in 2015. This figure is still much lower than the relevant figures for 2009-2010, when more than 8,000 children were returned every year. And yet, the interrupted positive trend should be taken as a warning - considering that the system of training and assisting future adopters and foster parents continues to evolve, this development reflects some hidden systemic changes. In particular, this 
dynamic may be a consequence of the high compensations for adopting siblings or children with disabilities introduced after the Federal Law 272-FZ (so-called Dima Yakovlev Law) came in force.

The main cited reason why children are returned to institutions is the will expressed by their replacement parents - adopters, guardians, or foster parents. Although the statistics does not contain information about the parents' motives, we might assume frustration, unjustified expectations or conflict with fostered children to be among them. It should be noted that during the last five years the share of this reason has been slowly declining: in 2011-2015 the share of returns initiated by replacement parents declined by 6.6 points, from $71.2 \%$ to $64.6 \%$ (Fig. 7). Unfortunately, the rate of repeat institutional placements on account of inadequate performance of caregivers does not show a similar trend. The share of such cases in the total number of returns during the last five years has consistently been $12 \%-15 \%$.

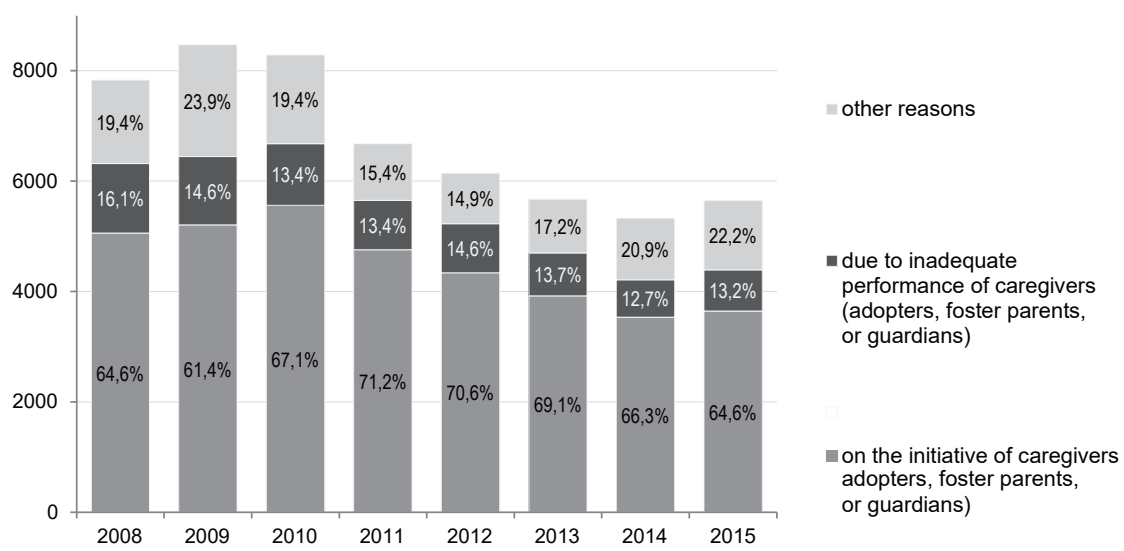

Figure 7. Number and structure of cancelled family placements, 2008-2015

Source: Estimates on the statistical form 103-RIK data

Preventing repeat orphanhood is one of the key tasks of the child protection services because repeated rejection can seriously traumatise the child and lead to the situation when the child is placed at an institution irreversibly because it is usually difficult to find a new family placement for children with such histories. The mechanisms to prevent repeat orphanhood include the development of a system of professional and psychological training for potentials carers, which would continue to be available for them after they take in a child, as well as improving the system of complex support for families and applying an individualized approach to working with families and children. 


\section{Absence of systemic effort to reunite biological families}

Given the high incidence of social orphanhood, some countries have adopted an approach whereby returning the child to his/her biological family is prioritized above all other care options, whether family-type or institutional (Biryukova, Varlamova 2014). The available statistical data clearly shows that returning a child to his/her biological family is not a priority for the Russian child protection services and officers handling the placements of children without parental care. In our estimate, the share of children reunited with their parents in the general population of children placed during a calendar year was gradually growing in 2008-2011, and now it is steadily declining, and so does the absolute number of children returned to their parents (Fig. 8). In 2015, only 5.8\% of children were returned to their biological parents. The reasons for the low prevalence of returns are the lack of methods for working with problematic biological families and the absence of formal motivation to promote returns for social workers. Since social services regularly report statistics on the total number of family placements, they are not interested in working with biological parents, because it usually requires more time and does not necessarily result in a successful child placement.

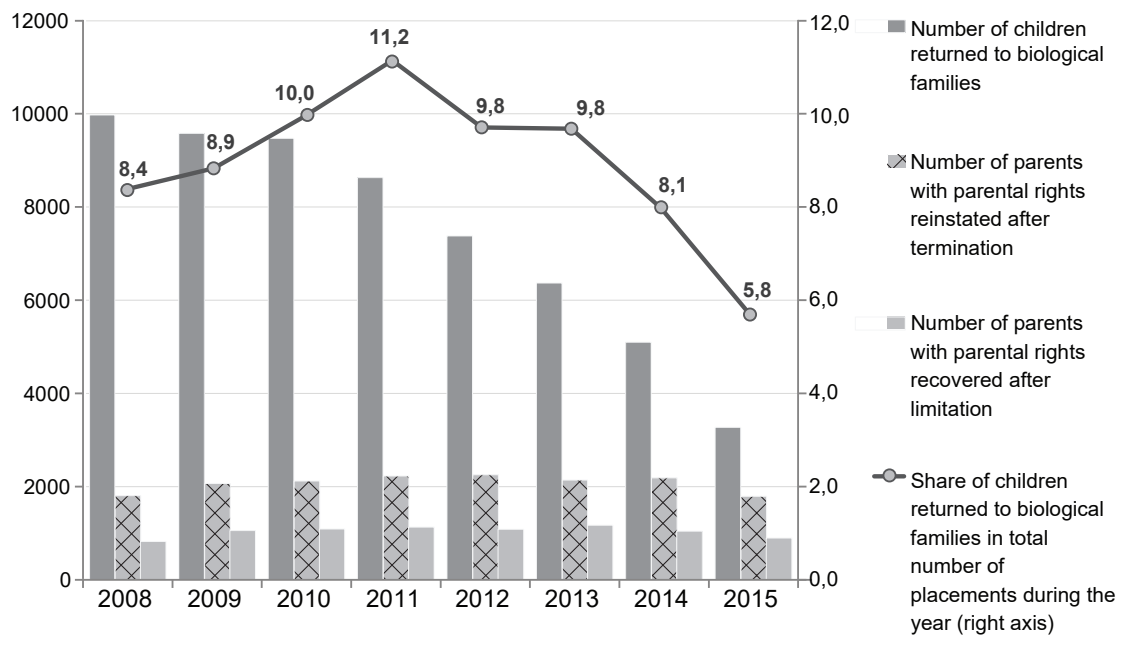

Figure 8. Number of children returned to their biological families, reinstatement of terminated and recovery of limited parental rights, 2008-2015

Source: Estimates on the statistical form 103-RIK data

The number of decisions reinstating parental rights to cancelled limitations shows a slightly less troubling trend. The number of parents whose parental 
right were reinstated rose gradually from 2008 to 2011, from 1,810 to 2,256. Later, however, there was a drop in the number again, and the figure for the year $2015(1,797)$ was smaller than that for 2008. This is partly explained by the overall positive dynamics of restrictions described earlier. We see a similar pattern in the cases of lifting limitations of parental rights: from 2008 to 2011 the number of them was rising, from 822 to 1,129 , and then began to fall, going down to 895 in 2015.

Helping families and parents to overcome a crisis and reuniting biological families is one of the most important methods of preventing new incidents of social orphanhood in at-risk families. At the same time this is one of the mechanisms of preventing the reproduction of social orphanhood: maintenance of ties with biological parents and normalisation (whenever possible) of relations between children and their parents enhance emotional and social development of children and establish an idea of familial attachments. Given the ongoing deinstitutionalisation of child care, working with biological families should become one of new priorities in the system of identifying and placing at-risk children.

\section{Institutionalisation of children with health issues and limited vital functions}

Irrespective of their age, children challenged in terms of health and vital functions, or with developmental disabilities, have very little chance to get a family placement. There is no publicly available comprehensive data on the state of health and congenital conditions of children living in children's homes and residential care facilities of different types. Yet, the data published by Rosstat shows that as of 2014 in the general population of children at children's homes (children both with and without the official status of an orphan or a child without parental care) the share of physically challenged children was $42.4 \%$ and psychologically challenged children $67.1 \%$ (Rosstat 2015). Besides, the statistics of placements indirectly suggests that children challenged in terms of health and vital functions are in a more vulnerable position. Thus, according to the 103-RIK form, the population of children without permanent placement consistently has had a large share of children temporarily placed in specialized institutions for children in need of social rehabilitation or in hospitals. In 2012, they accounted for more than $90 \%$, then the figure began to fall, but even in 2015 it was about $80 \%$ of children without permanent placement. This means that the population of children who do not get a placement during a calendar year consists predominantly of children in need of a special psychological or medical care.

Finding a solution for this situation will undoubtedly require additional resources, either for a specialized training for potential foster parents or other carers, for enhancing their social, psychological, financial and sometimes medical support, or creating at institutions a family-type environment to accommodate such children. This task, at the present stage, is becoming a priority for the system of the placement of children without parental care. 


\section{Conclusions and Discussion}

The analysis of the official statistics shows that in Russia the total number of children out of parental care has been steadily declining since 2009 and reached $2.1 \%$ in the total number of children under 18 years old by 2015 . However, the primary risk of orphanhood, either biological or social, remains high, although it has also declined during the last 15 years. In $2015,0.20 \%$ of children under the age of seventeen were taken out of parental care, and in 2000, this figure reached $0.36 \%$. Over the same period, the total number of institutionalised children out of parental care dropped by more than two-thirds, falling to 59,000 children in 2015 from 180.3 thousand children in 2000, which is clearly a result of the systematic deinstitutionalisation policy. In parallel, placements with foster families are gradually replacing guardianship and, to some extent, even adoptions.

At the same time, the current child welfare system retains three problematic phenomena. They are the high prevalence of repeat orphanhood (or returns from family placements) which went back up in the years following the introduction of new benefits for domestic adoptions, rare biological family reunions, and the chronic institutionalisation of children with disabilities. In addition, the statistics show a significantly higher share of children at school age and older among those living in institutions. It is in this way that Russian institutional care eventually accumulates children needing specific care and support, which requires a much more individual approach and casework together with the renovation of institutional care for those remaining in it.

In 2014, the adoption of Decree № 481 marked a new stage in the evolution of the Russian child welfare system. These legislative changes in general respond to the aforementioned challenges as they drastically transform the structure and goals of the institutional care system. The Decree highlights the temporary character of the institutional placements and sets new standards for the functioning for the institutions starting from September 2015. These standards imply a whole range of revolutionary changes to the current model of institutional care, starting from the principles of arranging educational groups and appointing caregivers and going up to the organization of residential space and technical facilities in the buildings. Thus, prior to the reforms, the Russian system of childcare, using the language of attachment theory, consisted of two segments, the harmful or 'improper' institutional segment and the 'proper' family placements. These new changes, if implemented, will put the institutional care system in line with the attachment theory postulates. However, in 2016, it became clear that the implementation of this reform might be challenged by legislative, administrative, and financial constraints, which became particularly explicit due to the recent economic downturn and the ensuing budget cuts.

\section{Acknowledgements}

The research was carried out within the framework of the Basic Research Program at the National Research University Higher School of Economics (HSE) in 2017. 


\section{References}

Ainsworth M. S., Bowlby J. (1991) An Ethological Approach to Personality Development. American Psychologist, 46(4): 333-341.

Biryukova S., Varlamova M. (2014) Obzor semeynykh form ustroystva detey-sirot v stranakh Severnoy, Kontinental'noy i Yuzhnoy Evropy [The Overview of the Forms of Fostering of Orphaned Children in Northern, Continental and Southern Europe]. SPERO. Sotsial'naya politika: ekspertiza, rekomendatsii, obzory [SPERO. Social Policy: Expertise, Recommendations, Overviews], (19): 103-112.

Biryukova S., Varlamova M., Sinyavskaya O. (2013) Sirotstvo v Rossii: osnovnye tendentsii i prioritety gosudarstvennoy politiki [Orphanhood in Russia: Major Trends and Priorities of State Policy]. SPERO. Sotsial'naya politika: ekspertiza, rekomendatsii, obzory [SPERO. Social Policy: Expertise, Recommendations, Overviews], (18): 57-80.

Decree of the Government of the Russian Federation (2001) O detskom dome semeynogo tipa [On the Family-Type Children's Home] N 195 from 19.03.2001.

Decree of the Government of the Russian Federation (2014) O deyatel'nosti organizatsiy dlya detey-sirot i detey, ostavshikhsya bez popecheniya roditeley, $i$ ob ustroystve $v$ nikh detey, ostavshikhsya bez popecheniya roditeley [On the Activity of Organizations for Orphan Children and Children without Parental Care and on Placement of Children without Parental Care in Them] N481 from 24.05.2014.

Dozier M., Zeanah C.H., Wallin A. R., Shauffer C. (2012) Institutional Care for Young Children: Review of Literature and Policy Implications. Social Issues and Policy Review, 6(1): $1-25$.

Family Code (1995) Semeynyy kodeks Rossiyskoy Federatsii [Family Code of the Russian Federation] N223-FZ from 29.12.1995.

Federal Law (2012) O merakh vozdeystviya na lits, prichastnykh k narusheniyam osnovopolagayushchikh prav $i$ svobod cheloveka, prav i svobod grazhdan Rossiyskoy Federatsii [About Corrective Actions on the Persons Involved in Violations of Fundamental Human Rights and Freedoms, Rights and Freedoms of Citizens of the Russian Federation] N272FZ from 28.12.2012.

Groark C. J., Muhamedrahimov R. J., Palmov O. I., Nikiforova N. V., McCall R. B. (2005) Improvements in Early Care in Russian Orphanages and their Relationship to Observed Behaviors. Infant Mental Health Journal, 26(2): 96-109.

Ovcharova L., Yarskaya-Smirnova E. (eds.) (2010) Faktory semeynogo neblagopoluchiya i mekhanizmy profilaktiki sotsial'nogo sirotstva: rezul'taty analiza i rekomendatsii [Factors of Family Problems and Mechanisms of Prevention of Child Abandonment: the Results of the Analysis and Recommendations], Moscow: IISP.

Rosstat (2015) Sotsial'noe polozhenie i uroven' zhizni naseleniya Rossii [Social Status and Standard of Living of the Russian Population]. Available at: http://www.gks.ru/bgd/regl/ b15_44/Main.htm (accessed 10 October 2016). 
Semja G. V. (2012) Deinstitucionalizaciya detej-sirot: reformirovanie seti uchrezhdenij internatnogo tipa i razvitie spektra uslug dlya detej i semej [De-Institutionalisation of Orphans: The Reform of the Network of Residential Care and the Development of the Range of Services for Children and Families], Moscow: Variant.

Rosstat (2014) Education/Children out of parental care. Available at: http://www.gks.ru/ wps/wcm/connect/rosstat_main/rosstat/ru/statistics/population/education/ (accessed 14 April 2017).

UNICEF (2012) Children under the age of three in formal care in Eastern Europe and Central Asia. A Rights-Based Regional Situation Analysis, Geneva: UNICEF.

Williamson J., Greenberg A. (2010) Families, not Orphanages, New York: Better Care Network. 